\title{
Density of Pollution Indicator Bacteria in Relation to Physicochemical Factors During Diel Cycle of River Ganga at Ichapore, West Bengal, India
}

\author{
Sankar Narayan Sinha*, Dipak Paul \\ Environmental Microbiology Research Laboratory, Department of Botany, University of Kalyani, Kalyani, West Bengal, India \\ Email address: \\ sinhasn62@yahoo.co.in (S. N. Sinha),dipak23paul@yahoo.com (D. Paul)
}

\section{To cite this article:}

Sankar Narayan Sinha, Dipak Paul. Density of Pollution Indicator Bacteria in Relation to Physicochemical Factors During Diel Cycle of River Ganga at Ichapore, West Bengal, India. Frontiers in Environmental Microbiology. Vol. 1, No. 1, 2015, pp. 9-13.

doi: $10.11648 /$ j.fem.20150101.12

\begin{abstract}
A diurnal study was undertaken in April 2014 to record the bacterial density and some of the physicochemical factors of the river Ganga near Ichapore, West Bengal, India. The pollution indicating bacteria (total coliform, faecal coliform and faecal streptococci) were found in maximum numbers at $14.00 \mathrm{hrs}$ and minimum at $20.00 \mathrm{hrs}$. All the bacterial populations were abundant and showed diel rhythm. The physicochemical parameters (temperature, $\mathrm{pH}$, dissolved oxygen (DO), bicarbonate, total hardness, calcium hardness and electrical conductivity) also showed diurnal fluctuation pattern. The total coliform showed significant positive correlation with temperature, $\mathrm{pH}$ and electrical conductivity whereas the faecal coliform showed significant inverse correlation with DO. On the other hand, faecal streptococci showed significant positive correlation with temperature, $\mathrm{pH}$ and electrical conductivity and significant inverse correlation with DO. The river water in this areas needs a substantial degree of purification treatment before use.
\end{abstract}

Keywords: Pollution, Diel Cycle, River Ganga, Physicochemical Factors, Pollution Indicating Bacteria

\section{Introduction}

Ichapore town $\left(22.8000^{\circ} \mathrm{N}, 88.3667^{\circ} \mathrm{E}\right)$ of West Bengal, India lies on the eastern bank of the river Ganga. It serves as mother dustbin for several industries and town sewage throughout the range in plains. At Debitala ghat near about 10 to 20 megagallon per day of domestic sewage from township is dumped regularly. The town serves a load of more than two lakhs of people while urbanization in all fronts are increasing day by day.

Little information is available on the pollutional load contributed by the drain water to the riverine ecosystem in this area. Several studies are conducted in India and abroad on different riverine ecosystem threatened with sewage pollution [1-4]. The aim of the present study was assess the degree of contamination by estimating the physicochemical properties and bacterial pollution load of the drain water caused by the continuous discharge of the raw effluents into the river.

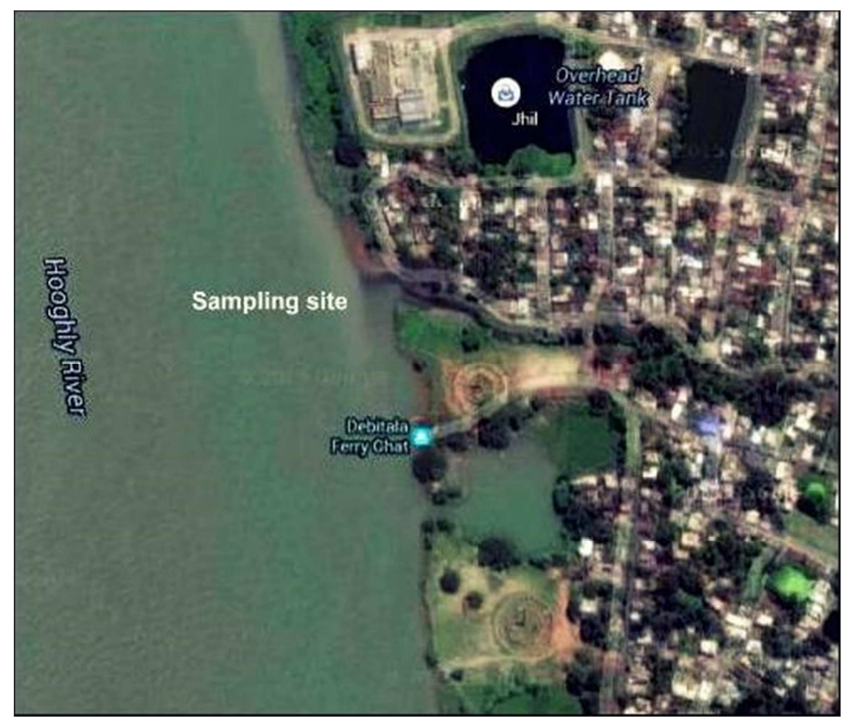

Figure 1. Stretch of the river Ganga (Hooghly river) showing sampling site. 


\section{Materials and Methods}

\subsection{Sampling}

After the preliminary survey of the Ganga river, the spot was selected keeping in mind its accessible position at night for the study of diel fluctuations. The water samples were collected from Debitala ghat, a sewage outfall area of river Ganga at Ichapore town, West Bengal (fig 1). For the investigation of fluctuation in physico-chemical and bacterial parameters, water samples were collected at few hours interval for $24 \mathrm{hrs}$, i.e. $9.00 \mathrm{hrs}, 12.00 \mathrm{hrs}, 14.00 \mathrm{hrs}, 17.00$ hrs and 20.00 hrs. Water samples were collected in sterilized glass bottles aseptically and transported to the laboratory in an ice bucket.

\subsection{Analysis of Physicochemical Parameters of Water Samples}

Physico-chemical parameters of the water were analyzed following standard methods [5]. Parameters like temperature, $\mathrm{pH}$, Dissolved oxygen (DO), bicarbonate, total hardness, calcium hardness and electrical conductivity were measured in the laboratory.

\subsection{Bacteriological Analysis}

The various pollution indicating bacteria were isolated on selective medium such as eosine methylene blue medium [6] for total coliform and faecal coliform (FC), and sodium azide medium [7] for faecal Streptococci (FS). For isolation of total coliform incubation were done at $37^{\circ} \mathrm{C}$ whereas for faecal coliform and faecal Streptococci incubation were done at $44.5^{\circ} \mathrm{C}$.

\subsection{Enumeration of Bacteria}

Bacterial counts were made following five tube most probable number (MPN) method [6].

\subsection{Statistical Analysis}

All experiments were carried out in triplicate, and the results were expressed as the mean. Experimental data were analyzed by using the SPSS 13.0 software package.

\section{Results and Discussion}

The results indicated that the river water temperatures showed a definite diurnal trend (fig 2). An increase in temperature during the daytime and decrease in the night hours was observed. The lowest water temperature $\left(18^{\circ} \mathrm{C}\right)$ was recorded at 20.00 hours in the night. The maximum temperature $\left(29^{\circ} \mathrm{C}\right)$ was noted at 14.00 hours. The river water was alkaline throughout the diel cycle ranging between 7.2 and $8.2 \mathrm{pH}$ (fig 3). Usually lower $\mathrm{pH}$ was observed during night. This might be due to the appearance of free $\mathrm{CO}_{2}$. It also increases the bicarbonae concentrations [8]. The conversion of $\mathrm{CO}_{3}$ to free $\mathrm{CO}_{2}$ depicts the change in the buffer system which lowers the $\mathrm{pH}$.

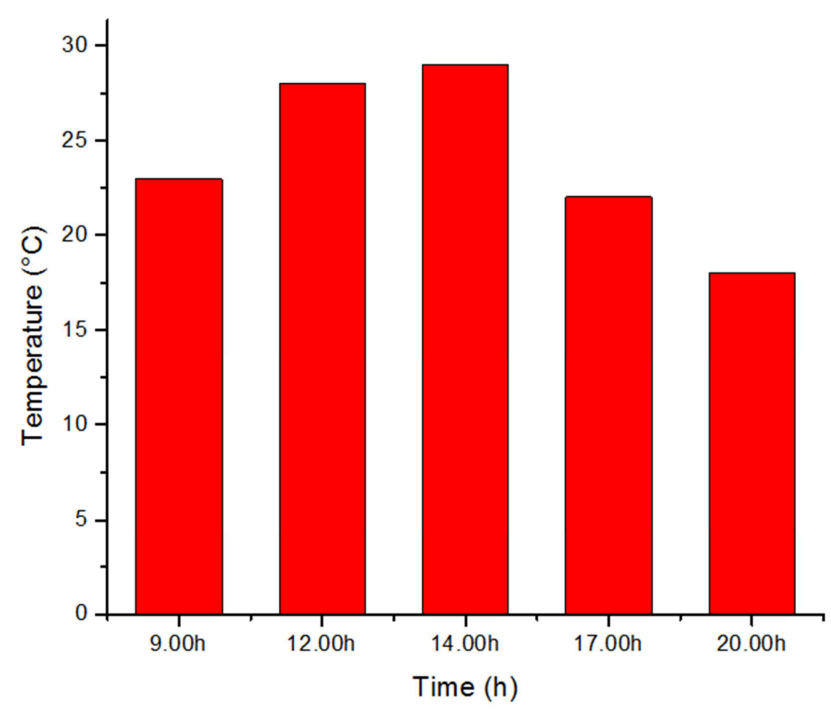

Figure 2. Diurnal variation in temperature of the river Ganga.

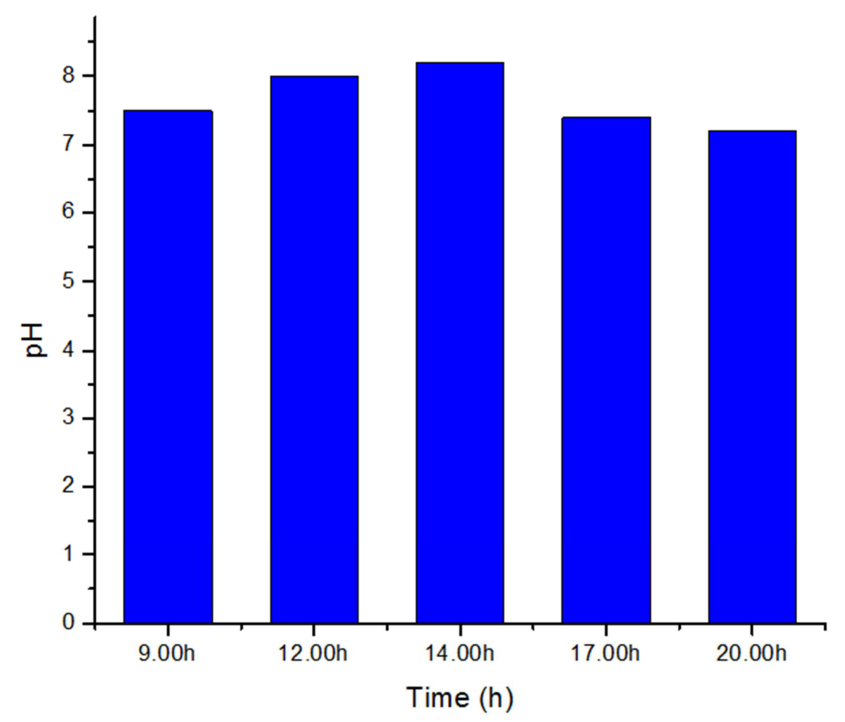

Figure 3. Diurnal variation in $\mathrm{pH}$ of the river Ganga.

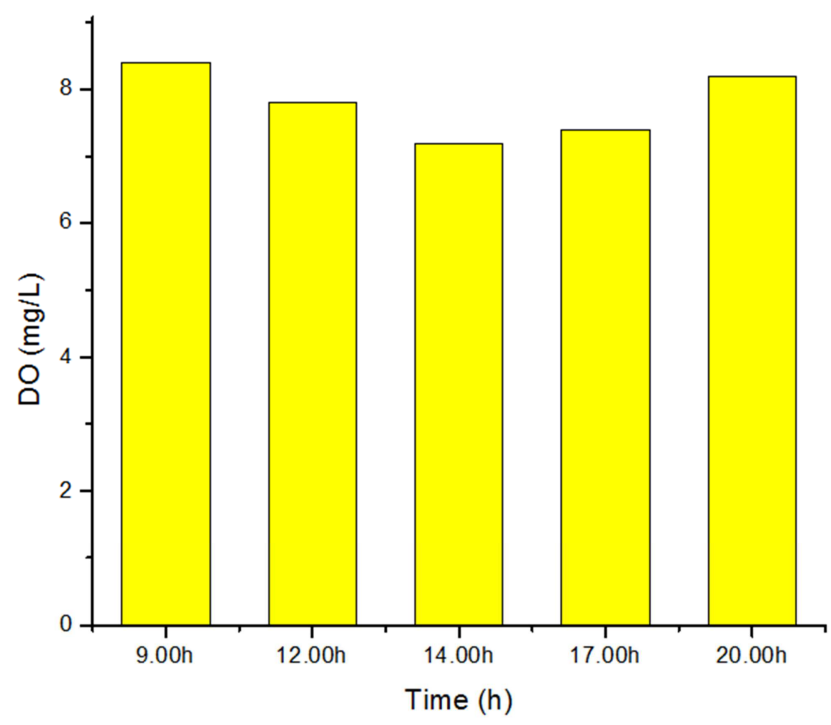

Figure 4. Diurnal variation in DO of the river Ganga. 


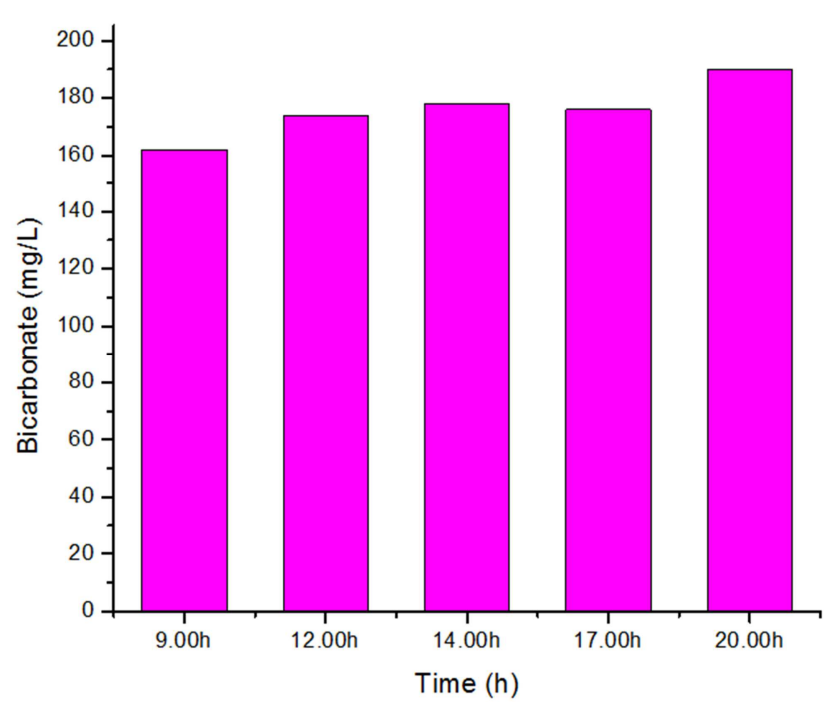

Figure 5. Diurnal variation in bicarbonate of the river Ganga.

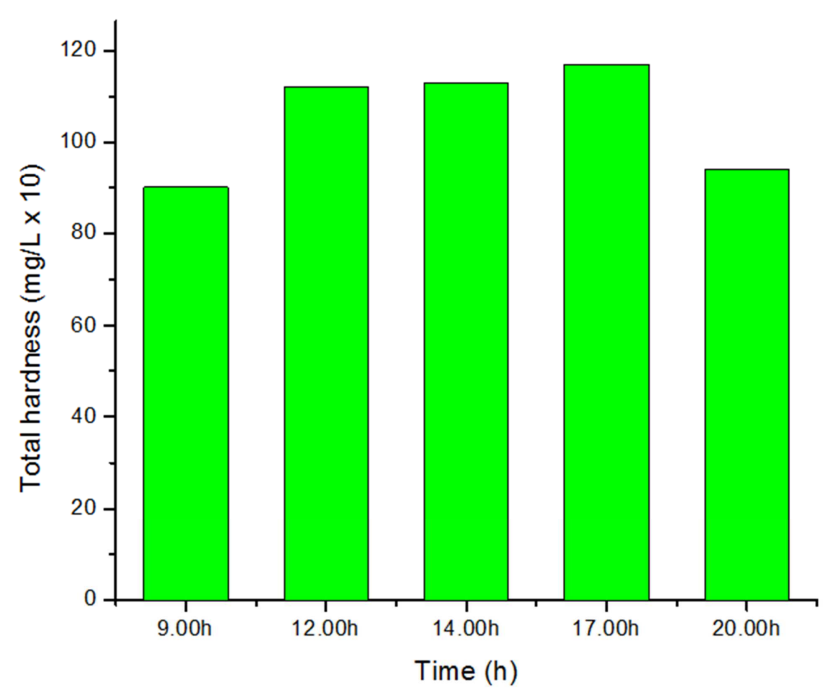

Figure 6. Diurnal variation in total hardness of the river Ganga.

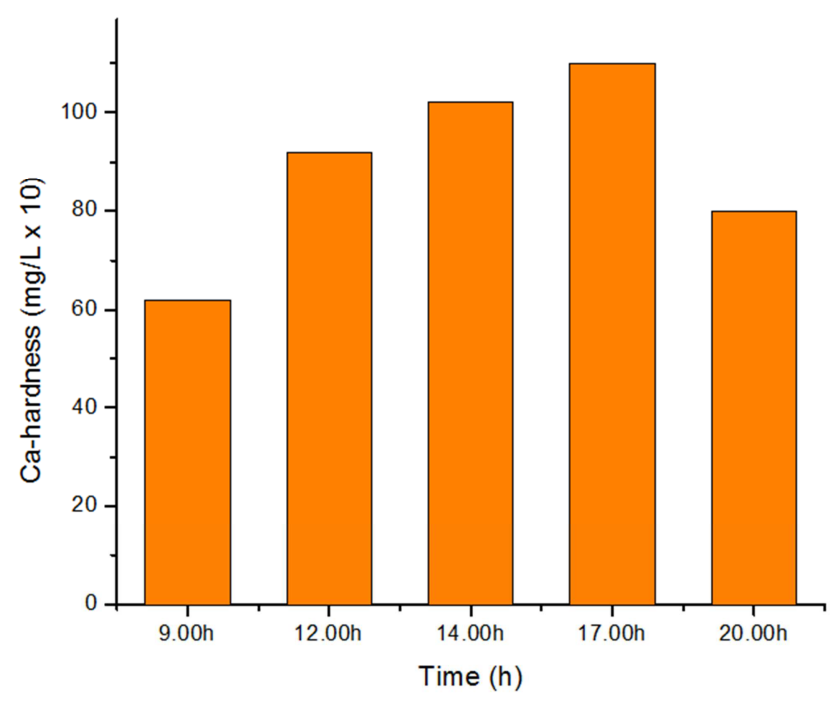

Figure 7. Diurnal variation in Ca-hardness of the river Ganga.

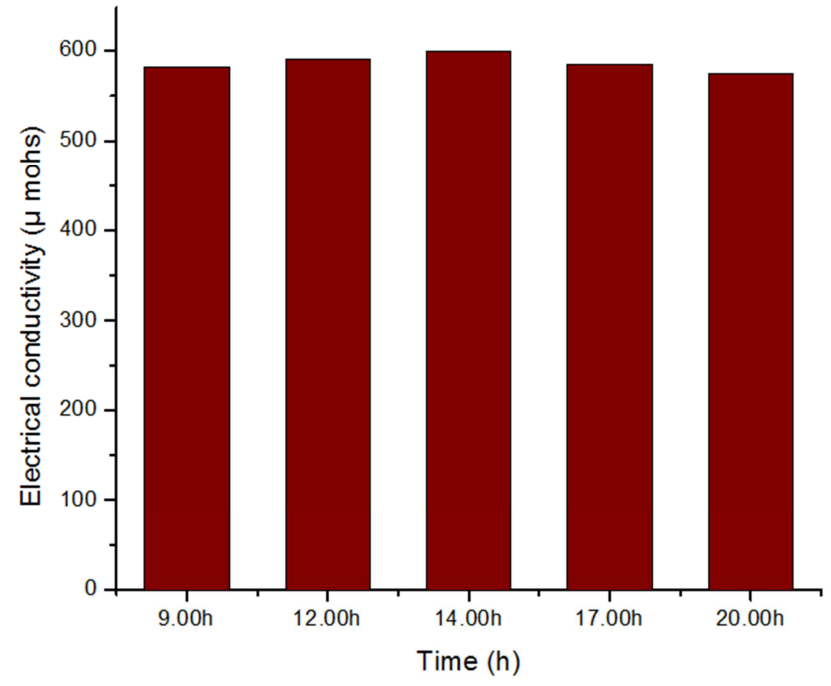

Figure 8. Diurnal variation in electrical conductivity of the river Ganga.

The DO ranged from 7.2 to $8.4 \mathrm{mg} \mathrm{L}^{-1}$ (fig 4). It was recorded maximum at 9.00 hours $\left(8.4 \mathrm{mg} \mathrm{L}^{-1}\right)$ and minimum at 14.00 hours $\left(7.2 \mathrm{mg} \mathrm{L}^{-1}\right)$. The high concentration of DO in the morning is due to low temperature which enhances the oxygen dissolving capacity [9]. During daytime, the higher dissolved oxygen might be due to increased photosynthetic activity [10]. The increase in temperature degraded the DO concentration at 12.00 hours which showed the inverse relation between temperature and DO (Table 1).

Bicarbonate values ranged between $162-190 \mathrm{mg} \mathrm{L}^{-1}$ (fig 5). The total hardness (900-1170 $\mathrm{mg} \mathrm{L}^{-1}$ ) and calcium hardness (620-1100 $\left.\mathrm{mg} \mathrm{L}^{-1}\right)$ showed significant variation during diel cycle (fig 6 and 7). The electrical conductivity of water varied narrowly (575-600 $\mu$ mhos) (fig 8).

Table 1 showed correlation among different physicochemical parameters throughout the diel cycle. Significant positive correlations were noted between $\mathrm{pH}$ and temperature, electrical conductivity and temperature, $\mathrm{pH}$ and electrical conductivity, and total hardness and calcium hardness. On the contrary, significant inverse correlations were noted between total hardness and DO, and calcium hardness and DO. The correlation coefficient between physicochemical parameters and pollution indicator bacteria were presented in Table 2. The total coliform showed significant positive correlation with temperature, $\mathrm{pH}$ and electrical conductivity whereas the faecal coliform showed significant inverse correlation with DO. On the other hand, faecal streptococci showed significant positive correlation with temperature, $\mathrm{pH}$ and electrical conductivity and significant inverse correlation with DO.

The variation in bacterial load suggested distinct diurnal fluctuation. At 14.00 the MPN of coliforms remain at peak (30x10 $0^{4} \mathrm{MPN} / 100 \mathrm{ml}$ ) (fig 9). The MPN of faecal coliform and faecal Streptococi also recorded high $\left(12 \times 10^{4} \mathrm{MPN} / 100\right.$ $\mathrm{ml}$ and $8.2 \times 10^{4} \mathrm{MPN} / 100 \mathrm{ml}$ ) (fig 9). The ratio of faecal coliform and faecal streptococci is always more than one throughout the diurnal cycle depicting the faecal nature of sewage which is more hazardous (Table 3). When the faecal 
coliform to faecal streptococci ratio is below 0.7 , the contamination is said to be from nonhuman sources, and when the ratio is over 4.3 , it indicates anthropogenic contamination [11]. Therefore, the use of faecal coliform to faecal streptococci ratio may further define possible sources of faecal discharge to a stream. The results indicated the pollutional nature of river water caused by faecal matter. The capacity of high dilution capacity of river Ganga round the year is responsible for reduction of pollutional status of drain water in some extent.

Table 1. Simple correlation matrix among different physicochemical parameters. Values were significant at 1\% (**) and 5\% (*) level.

\begin{tabular}{lllllll}
\hline & Temp & pH & DO & TH & Bicarbonate & Ca-hardness \\
\hline Temp & 1 & & & & & \\
pH & $0.982^{* *}$ & 1 & & & & \\
DO & -0.563 & -0.581 & 1 & & & \\
TH & 0.562 & 0.533 & $-0.919^{*}$ & 1 & & \\
Bicarbonate & -0.375 & -0.225 & -0.196 & 0.118 & 1 & 1 \\
Ca-hardness & 0.339 & 0.346 & $-0.934^{*}$ & $0.949^{*}$ & 0.360 & 0.537 \\
EC & $0.934^{*}$ & $0.944^{*}$ & -0.777 & 0.673 & -0.209 & 1 \\
\hline
\end{tabular}

Table 2. Simple correlation coefficient (r) between physicochemical parameters and bacteriological parameters. Values were significant at $1 \%(* *)$ and $5 \%(*)$ level.

\begin{tabular}{llll}
\hline & Total coliform & Faecal coliform & Faecal streptococci \\
\hline Temperature & $0.932^{*}$ & 0.493 & $0.944^{*}$ \\
pH & $0.947^{*}$ & 0.521 & $0.910^{*}$ \\
DO & -0.710 & $-0.933^{*}$ & $-0.770^{*}$ \\
TH & 0.577 & 0.731 & 0.800 \\
Bicarbonate & -0.256 & 0.099 & -0.271 \\
Ca-hardness & 0.439 & 0.782 & 0.614 \\
EC & $0.992^{* *}$ & 0.765 & $0.942^{*}$ \\
\hline
\end{tabular}

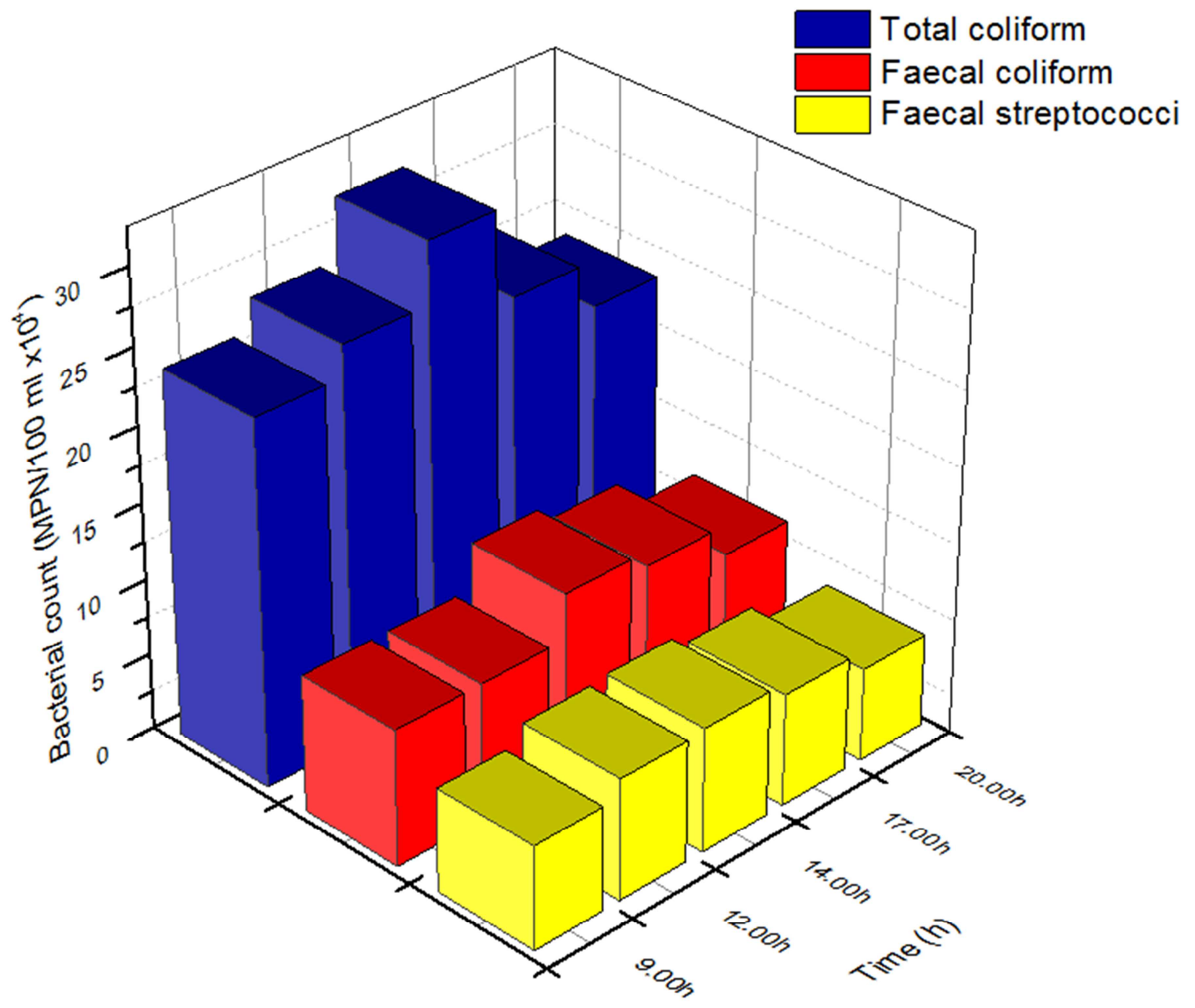

Figure 9. Diurnal variation in total coliform, faecal coliform and faecal streptococci count of the river Ganga. 
Table 3. Ratio of faecal coliform to faecal streptococci (FC/FS).

\begin{tabular}{ll}
\hline Time (hr) & FC/FS ratio \\
\hline 9.00 & 1.323 \\
12.00 & 1.125 \\
14.00 & 1.463 \\
17.00 & 1.486 \\
20.00 & 1.475 \\
\hline
\end{tabular}

\section{Conclusion}

It was concluded from this study that a marked diel variations were observed in selected physiological and bacteriological parameters during 24 hours. It was observed that river Ganga in this stretch is being heavily polluted by the discharge of sewage. It can thus be suggested that the water treatment plant should be installed in this area where the huge amount of sewage is being discharged continuously in the river.

\section{References}

[1] Tripathi BD, Sikandar M, Shukla SC (1991) Physico-chemical characterization of city sewage discharged into river Ganga at Varanasi, India. Environment International 17(5): 469-478.

[2] Wang XL, Lu YL, Han JY, He GZ, Wang TY (2007) Identification of anthropogenic influences on water quality of rivers in Taihu watershed. Journal of Environmental Sciences 19(4): 475-481.
[3] Suthar S, Sharma J, Chabukdhara M, Nema AK (2010) Water quality assessment of river Hindon at Ghaziabad, India: impact of industrial and urban wastewater. Environmental Monitoring and Assessment 165(1-4): 103-112.

[4] Paul D, Sinha SN (2013) Assessment of various heavy metals in surface water of polluted sites in the lower stretch of river Ganga, West Bengal: a study for ecological impact. Discovery Nature 6(14): 8-13.

[5] APHA (2005) Standard methods for the examination of water and wastewater. $21^{\text {st }}$ ed. American Public Health Association, Washington DC, USA.

[6] Seeley W, VanDemark J (1981) Selected exercise from microbes in action, $3^{\text {rd }}$ edition. W.H. Freeman and Co., New York, USA

[7] Baker FJ, Breach MR, Leighton I, Taylor P (1980) Medical microbiological techniques. Butterworths. London, England.

[8] Khalaf AN, MacDonald LJ (1975) Physicochemical conditions in temporary ponds in the new forest. Hydrobiologia 47(2): 301-318.

[9] Bohra OP (1977) Observations on the diel cycle of abiotic parameters at Jatabera, Jodhpur. Comparative Physiology and Ecology 2: 115-118.

[10] Hutchinson GE (1957) A Treatise on Limnology. I. Geography, Physics, and Chemistry. Wiley, New York. 1015.

[11] Geldreich EE, Best LC, Kenner BA, Van Donsel DJ (1967) The bacteriological aspects of stormwater pollution. U. S. Dept. of Health, Education and Welfare, Washington, D.C. 